\title{
Pronouns in Arigidi: A Syntactic Analysis
}

\author{
Boluwaji Oshodi \\ Adekunle Ajasin University \\ Bolanle Fokule Adekeye \\ University of Ilorin
}

\section{Introduction}

Traditional grammarians classified lexical items into parts of speech and one of such classifications is the pronoun. According to Dineen (1967), a pronoun is a part of speech that can substitute for the proper name of anyone and that indicates a definite person. The Merriam-Webster Dictionary defines a pronoun as any of a small set of words in a language that are used as substitutes for nouns or noun phrases and whose referents are named or understood in the context word that can replace i.e. be used in place of a noun in a grammatical construction. This study examines pronouns in Arigidi (a little studied) speech form with the aim of gaining an insight into their forms, structure and function in line with the classification of traditional grammar. Arigidi and nine other speech forms classified under Arigidi Cluster, Lorena (Ethnologue 2012) are spoken in Àkókó region of Ondo state South-west Nigeria where Yorùbá is the major language. However, based on previous studies such as Greenberg (1963), Hoffman (1974), Bennet and Sterk (1977), Capo (1989), OhiriAnichie (2006), Oshodi (2011a), Lorena (Ethnologue 2012) and Olúwádorọ̀ (2014) their true linguistic status is still controversial and yet to be ascertained. This is what always makes any study on any of the speech forms interesting.

\section{The Concept of Pronoun in Yorùbá}

Prominent Yorùbá scholars such as Bámgbóséé (1967, 1990), Awóbùlúyì (1978) and Yusuf (1995) all define a pronoun as the word used instead of a noun. Bámgbóșe (1967) analyzes pronouns from the angle of syntactic position of occurrence. He defines a pronoun as a word that cannot have a qualifier in the nominal group. He observes further that pronouns have a system of number (singular and plural) and of person (1st, 2nd and 3rd person). Also, they have different forms for the different syntactic positions in which they occur. Awóbùlúyì (1978) and Bámgbóșe (1990) grouped Yorùbá pronouns into three; subject and object pronouns, possessive pronouns (genitival qualifiers) and the third type which Bámgbóse (1990) tagged "noun-like pronouns" because they possess some attributes of nouns in the language. Awóbùlúyì (1978) tagged this third type of pronouns emphatic pronouns. The other pronouns were tagged short pronouns while the emphatic pronouns were tagged long pronouns. In later grammatical theories however, these short and long (emphatic) pronouns were changed to weak and strong pronouns (Manfredi 1987 and Sells 1987). Today, following Ajíbóyè (2004) and Adéșọlá (2004; 2005), the short/weak pronouns and the long/strong pronouns are also called antilogophor and logophor respectively.

Awóbùlúyì (1978) using a functional approach observed that in Yorùbá language, the part of speech traditionally referred to as pronouns is actually a subgroup of nouns. Awóbùlúyì's claim is based on some specific functions performed by some words referred to as pronouns in Yorùbá particularly their position of occurrence and their relationship with other words in sentences. 
Though there is the principle of language universality, there are still language specific rules. Based on this, Awóbùlúyì's claim needs to be verified with facts from other African languages thus, the decision to examine pronouns in Arigidi. More so, since studies e.g. Awóbùlúyì (2008) and (Oshodi 2011; 2013; 2016a) have established a strong linguistic affinity between Arigidi and Yorùbá, it is hoped that findings from this study would help throw more light on the language subfamily to which Arigidi and the other speech forms belongs and in particular their true linguistic relationship with Yorùbá.

\section{Pronouns in Arigidi}

Following the concept of functional analysis, pronouns in Arigidi can be classified as subject and object as well as singular and plural. In addition to these, just like in Yorùbá, pronouns in Arigidi can be classified into two main types: short and long (emphatic) pronouns. There is also another type known as possessive pronouns (genitival qualifiers). Apart from the main function, which is to replace a noun in a sentence, pronouns in Arigidi perform other functions depending on their type and form. These functions shall be discussed under each type of pronoun.

\subsection{Short Pronouns in Arigidi}

The short pronouns in Arigidi can be grouped in terms of function (i.e. subject or object) and in terms of number (i.e. singular and plural). Below are the forms of the short pronouns in Arigidi:

Subject position

first person singular
second person singular
third person singular
First person plural
second person plural
third person plural

Table 1. Arigidi Short Pronouns

\begin{tabular}{llll} 
& & \multicolumn{2}{l}{ Object position } \\
man & "I" & min & "me" \\
ran & "you (sg)" & rin & "you (sg)" \\
$(a ́) ?$ & "he/she/it" & $\varnothing$ & "him/her/it" \\
óa "we" & "w & "us" \\
mán "you (pl)" & mẹn & "you (pl)" \\
wá & "they" & wá & "them"
\end{tabular}

To substantiate the above claim and forms, the pronouns are used in sentences below:

(1a) Man da ìyì ẹhẹ I buy two hen "I bought two hens"

(1b) Òjó á ri min Òjó HTS see me "Òjó saw me"

(2a) Rán jo ògòlòmàșí 2SG eat pawpaw "You(sg) ate pawpaw" 
(2b) Títí á rí rin

Títí HTS see 2SG

"Títí saw you"

(3a) Á(?) fọ àlà

3SG wash cloth

"He/she washed some clothes"

(3b) Òjó á ri $\varnothing$

Òjó HTS see NP

"Òjó saw him/her/it"

(4a) Òa ve oso

we go house

"We went home"

(4b) Òjó á bá ò

Òjó HTS greet us

"Òjó greeted us"

(5a) Mán kọn okùba

2PL possess money

"You(pl) are rich"

(5b) Títí á rọ̀n mẹ́n

Títí HTS know 2PL

"Títí knows you(pl)"

(6a) Wá bọ èjin they drink water

"They drank water"

(6b) Òjó á pún wá Òjó HTS abuse them

"Òjó abused them"

However, facts from the speech form revealed that the forms in (1-6) attested at the surface structure in basic declarative sentences as short pronouns in subject positions were all derived. They were actually derived from their underlying forms through some phono-syntactic processes. These underlying forms always occur in specific subject positions in some constructions. The underlying and surface forms of the short subject pronouns are shown below: 


\begin{tabular}{llll} 
& Underlying Form & & Surface Form \\
first person singular & min & $\rightarrow$ & man \\
second person singular & rin & $\rightarrow$ & rán \\
third person singular & $\varnothing$ & $\rightarrow$ & $\varnothing$ \\
first person plural & $\grave{a}$ & $\rightarrow$ & $\grave{o} a$ \\
second person plural & mén & $\rightarrow$ & mán \\
third person plural & wé & $\rightarrow$ & wá \\
\multicolumn{2}{l}{ Table 2. The Underlying and Surface Forms of Arigidi Short Pronouns }
\end{tabular}

Consider the examples below which show the sequential processes of how the surface forms (i.e. those listed in table (1) as subject forms) were derived from their underlying forms:

\begin{tabular}{|c|c|c|c|c|c|c|c|c|c|c|}
\hline \multicolumn{4}{|c|}{ Underlying form } & \multicolumn{4}{|c|}{ Assimilation/Merging } & \multicolumn{2}{|c|}{ Surface form } & \multirow{2}{*}{$\begin{array}{l}\text { Gloss } \\
\text { "I went/have gone" }\end{array}$} \\
\hline Min & á & vè & $\rightarrow$ & Man & á & vè & $\rightarrow$ & Man & vè & \\
\hline I & HTS & go & & I & HTS & go & & I & go & \\
\hline Rin & á & vè & $\rightarrow$ & Ran & á & vè & $\rightarrow$ & Rán & vè & "You went/have gone" \\
\hline $2 \mathrm{SG}$ & HTS & go & & $2 \mathrm{SG}$ & HTS & go & & $2 \mathrm{SG}$ & go & \\
\hline [Ø] & á & vè & $\rightarrow$ & NA & & & $\rightarrow$ & Á & vè & "3SG went/has gone" \\
\hline NP & HTS & go & & NA & & & & HTS & go & \\
\hline Ò & á & vè & $\rightarrow$ & Òá & vè & & $\rightarrow$ & Òa & vè & "We went/have gone \\
\hline we & HTS & go & & we & go & & & we & go & \\
\hline Mẹn & á & vè & $\rightarrow$ & Mán & á & vè & $\rightarrow$ & Mán & vè & "You went/ have gone" \\
\hline 2PL & HTS & go & & $2 \mathrm{SG}$ & HTS & go & & $2 \mathrm{PL}$ & go & \\
\hline Wẹ́ & á & vè & $\rightarrow$ & & á & Wá & $\rightarrow$ & Wá & vè & "They went/ have gone" \\
\hline they & HTS & go & & they & HTS & go & & they & go & \\
\hline
\end{tabular}

In examples $(1 \mathrm{~b}, 2 \mathrm{~b}, 3 \mathrm{~b}, 4 \mathrm{~b}, 5 \mathrm{~b}, 6 \mathrm{~b}$ and $7-12)$, we notice the occurrence of the morpheme $a$ between the subject NP and the verb. This element has been tagged the high tone syllable HTS ${ }^{1}$. The HTS assimilates the last vowel of the pronouns. The HTS is then deleted and its tone gets transferred to the assimilated vowel of the preceding pronouns to produce the surface forms listed in table 1. In example (9), the pronoun is presumed to be covert and the first overt element is the HTS $a$ thus, the processes of assimilation and deletion were not applicable. In example (7), the tone of the HTS was not transferred to the assimilated vowel of the pronoun for a good reason. This was to avoid metonymy with the second person plural pronoun mán "you(plural)". If this had not been done, the two forms would have been realized as (mán). In (10), instead of assimilation it was merging that took place. The HTS did not assimilate the underlying form of the first person plural $o$ "we" in order to avoid metonymy again. If assimilation had taken place, the first person plural pronoun would have been realized as $\dot{a}$ and the construction in (10) would be realized as $\dot{A}$

\footnotetext{
${ }^{1}$ The HTS is an overt element which occurs between the subject NP and the verb in Arigidi declarative sentence. It is similar to the one found in Yorùbá and its dialects. Oshodi (2011a, 2011b, 2013 and 2016a) in corroboration with the claim of Awobuluyi (1992) refers to it as a preverbal element, a tense and aspectual marker.
} 
ve the exact surface form in (9). The tone of the HTS was however deleted and the surface form was realized as $\dot{o} a$. Also, in (11 and 12), there was no need to transfer the tone of the HTS since the underlying forms carry the same high tone on the HTS.

Also, it was observed that the third person singular pronoun in the object position is covert. It has no form and it is not realized at all in Arigidi. This is why it is represented with the null sign $(\varnothing)$ in example (3b).

Another very important observation has to do with the actual form of the 3 SG subject pronoun. The morpheme $a$ which appeared in that position in (3a) has a question mark in front of it. This was purposely done to draw attention to its controversial form. Oshodi (2011b, 2013) claim that the form $a$ is not the 3SG short subject pronoun in Arigidi but the same HTS which assimilates or merges with the underlying forms to produce the surface forms as shown in (7-12). He (Oshodi) also failed to propose a form for the 3SG short subject pronoun.

In this study, the vowel [i] with a high tone is proposed as the underlying form of the 3SG subject pronoun in Arigidi based on its occurrence in some positions where the 3SG subject pronoun usually occurs in Arigidi constructions. Consider the examples below:

$\begin{array}{lll}\text { Í } & \text { sí } & \text { oso } \\ 3 \mathrm{SG} & \text { be } & \text { house }\end{array}$

"He/she is at home"

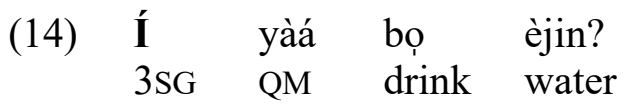

"Has he/she drunk water?"

Example (13) is a simple sentence while (14) is a question. Also, the form wé is proposed as the underlying form of the third person plural subject pronoun in Arigidi based on its position of occurrence in constructions where the third person plural subject pronoun normally occurs. Consider examples (21 and 22) below:

$$
\begin{aligned}
& \text { Rin sí oso } \\
& 2 \mathrm{SG} \text { be house } \\
& \text { "You(sg) are at home" }
\end{aligned}
$$

$$
\begin{array}{lll}
\text { Rin yàá bo èjin? } \\
2 \mathrm{SG} \text { QM drink } & \text { water } \\
\text { "Have you(sg) } & \text { drunk water?" }
\end{array}
$$

(17) Ò sí oso

we be home

"We are at home"

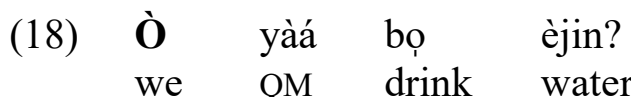

"Have we drunk water?" 
(19) Mẹ́n si oso

2PL be house

"You are at home"

(20) Mẹ́n yàá bọ èjin?

2PL QM drink water

"Have you(pl) drunk water?"

(21) Wẹ́ sí oso

they be house

"They are at home"

(22) Wẹ́ yàá bọ èjin?

they QM drink water

"Have they drunk water?"

Proposing wé as the underlying form of the third person plural subject pronoun can be substantiated by the fact that it is the only form that can occur in the position of the third person plural subject (21 and 22) in constructions where the other underlying forms can occur as shown in examples (13-20).

As shown in examples (1-22), the major function of the short pronouns in Arigidi both in subject and object positions is to replace a noun or a noun phrase in a sentence. For example, (14, $22,3 \mathrm{~b}$ and $6 \mathrm{~b})$ above can be rendered as $(23,24,25$ and 26$)$ below:

(23) Ginrin ukọnrẹn yàá bọ èjin?

This man QM drink water

"Has this man drunk water?"

(24) Òjó wọ̀nrin Títí yàá bọ èjin?

Òjó and Títí QM drink water

"Have Òjó and Títí drunk water?"

$\begin{array}{llll}\text { Òjó } & \text { á } & \text { rí } & \text { Títí } \\ \text { Òjó } & \text { HTS } & \text { see } & 3 \mathrm{SG} \\ \text { "Òjó saw Títín }\end{array}$

$\begin{aligned} & \text { Òjó á } \\ & \text { Òjó pún àk }\end{aligned}$ abuse all
"Òjó abused all the children"

In (23), the NP subject ginrin ukoren "this man" was replaced with the 3SG subject pronoun $i$ in (14) while in (24) the NP subjects Ojó and Títí were replaced with the pronoun wé in (22). Also, in (25), the NP object Tití was replaced with the 3SG object pronoun represented with $\varnothing$ because it is always covert in Arigidi in (3b) while in (26) the NP object àkùkù igbẹeji àwọ́rín "all the children" was replaced with the pronoun wá in (6b). 


\subsection{The Long (Emphatic) Pronouns in Arigidi}

There is another set of pronouns in Arigidi known as long or emphatic pronouns. Apart from the fact that they are differentiated for number and person, pronouns in this class function and behave just like the ordinary nouns in the language. Awóbùlúyì (1978) referred to them as a sub-class of nouns in standard Yorùbá. This set of pronouns in Arigidi behave exactly like those in Standard Yorùbá. The long (emphatic) pronouns are attested only in the subject position and they are shown below:

\begin{tabular}{lll} 
first person singular & amẹ̀n & "I" \\
second person singular & arọ́n & "you (sg)" \\
third person singular & úwọ́n/ẹ̀rẹ̀n & "he/she/it" \\
first person plural & aò & "we" \\
second person plural & ámẹn & "you (pl)" \\
third person plural & áwá & "they" \\
\multicolumn{2}{r}{ Table 3. Forms of the Long (Emphatic) Pronouns in Arigidi }
\end{tabular}

The long (emphatic) pronouns in Arigidi perform some specific grammatical functions. One of such functions is that they (long or emphatic pronouns) are the only types of pronouns that can be focused just like nouns in Arigidi. Consider the examples below:

$\begin{array}{llll}\text { Amẹ̀n } & \text { wọ́n } & \text { bọ } & \text { èjin } \\ \text { I } & \text { FOC } & \text { drink } & \text { water }\end{array}$

"It was I who drank water"

$\begin{array}{llll}\text { Arọ́ } & \text { wọ́n } & \text { bọ } & \text { èjin } \\ \text { you(sg) } & \text { FOC } & \text { drink } & \text { water } \\ \text { "It was } & \text { you(sg) } & \end{array}$

"It was you(sg) who drank water"

(30) Aò wọ́n bọ èjin we FOC drink water

"It was we who drank water"

(31) Ámẹ́n wọ́n bọ èjin you(pl) FOC drink water "It was you(pl) who drank water"
Áwá wọ́n bọ èjin they FOC drink water "It was they who drank water" 
In examples (27-32), the long (emphatic) pronouns all in bold form were the focused items which were immediately followed by the focus marker wón which is italicized. The interesting thing about focusing in relation to pronouns in Arigidi is that it is only nouns and verbs that can be focused in the speech form. In actual fact, it is only nouns that can be focused in their basic form. Verbs must first be nominalized through partial reduplication just like in Standard Yorùbá and then moved to the initial part of the sentence before they can be focused (see Oshodi 2011a, 2016a). Also, the long (emphatic) pronouns in Arigidi can take modifiers. Consider the examples below:

$$
\begin{aligned}
& \text { aò gon-on } \\
& \text { we particular } \\
& \text { "We in particular" }
\end{aligned}
$$

$$
\begin{array}{ll}
\text { úwọ́n } & \text { gon-ọn } \\
3 \mathrm{SG} & \text { particular }
\end{array}
$$

"He/she/it in particular"

\section{ègédí ámẹ́n}

only me

"Only me"

$$
\begin{aligned}
& \text { ègédí arọ́n } \\
& \text { only 2SG } \\
& \text { "Only you(sg)" }
\end{aligned}
$$

In (33-36), the long (emphatic) pronouns in bold form took the modifiers which were italicized. Furthermore, the long (emphatic) pronouns can also be questioned by the interrogative word siré "what", a feature which is only possible with nouns in Arigidi. Consider the examples below:

$$
\begin{aligned}
& \text { Amẹ́n șìré } \\
& \text { I } \quad \text { QM } \\
& \text { "What about me?" }
\end{aligned}
$$
Aò șìré?
we QM

"What about us?"

(39) Úwọ́n șìré?

3SG QM

"What about him/her/it?"
Áwá șìré?
they QM
"What about them?" 


\section{(41) Ámẹ́n șìré? \\ 2PL QM}

"What about you (pl)?"

As shown in examples (37-41), the long (emphatic) pronouns in Arigidi were all questioned by the interrogative word siré "what" just like nouns. Based on the fact that the long (emphatic) pronouns in Arigidi can be focused, can equally take some qualifiers and also be questioned by the interrogative word șire "what" just like nouns in the speech form (see Oshodi 2011a), it would actually be correct to put them in the class of nouns in Arigidi as suggested for Standard Yorùbá (Awóbùlúyì 1978).

Also, notice that the 3SG long (emphatic) pronoun in Arigidi has two forms úwọ́n and èrện. These two forms perform different syntactic functions. As shown in (27-32), úwọ́n is used in focusing, it is also the form that can take modifiers as shown in (33-36) and the form that can be questioned with the interrogative word siré "what" as shown in (37-41). However, in logophoric construction which requires that a particular pronoun be used when someone's perspective is being reported, it is ẹrện that must be used in such context. Consider the example below:

$$
\begin{aligned}
& \text { Kộlá á hện péní ẹ̀rện á ận } \\
& \text { Kọ́la HTS say that himself HTS laugh } \\
& \text { "Kọ́lá said that he (Kọ́lá) laughed" }
\end{aligned}
$$

In example (42), which involves the third person singular long (emphatic) pronoun, it is ẹrẹ̀n that is used as the perspective of Kólá is being reported. This is because the pronoun here must refer to Kọlá. Thus, (43) below is not acceptable in the language.

$$
\begin{array}{lllllll}
\text { *Kọ́lá } & \text { á } & \text { hẹ́n } & \text { péní } & \text { úwọ́n } & \text { á } & \text { wọn } \\
\text { Kọ́lá } & \text { HTS } & \text { say } & \text { that } & \text { he/she } & \text { HTS } & \text { laugh }
\end{array}
$$

However, (43) above can be rendered as (44) below:

$$
\begin{aligned}
& \text { Kọ́lá á hẹ́n péní úwộn gọn-ọn á wọn } \\
& \text { Kọ́lá HTS say that he/she MOD HTS laugh } \\
& \text { "Kọlá said that he (another entity) in particular laughed" }
\end{aligned}
$$

The example in (44) becomes grammatical because the 3SG long (emphatic) pronoun úwọ́n in this context took a modifier gon-ọn which made it clear that the person in reference is not Kọ́lá.

\subsection{Possessive Pronouns (Genitival Qualifiers) in Arigidi}

Just like in Standard Yorùbá, there is another type of pronouns in Arigidi tagged possessive pronouns also called genitival qualifiers. As the name implies, pronouns in this class are used sorely to indicate ownership or possession when used with nouns. Consider the sentences below where these pronouns are attested in Arigidi.

$$
\begin{aligned}
& \text { Okùba ron } \\
& \text { money my } \\
& \text { "My money" }
\end{aligned}
$$


(46) Okùba rìn

money your(sg)

"Your(sg) money"

(47) Okùba àá

money 3SG.POSS

"His/her money"

(48) Àyù ùú

ress 3SG.POSS

"His/her dress"

(49) Èhaàjo òó

food 3SG.POSS

"His/her/its food"

(50) Ègírí ií

head 3SG.POSS

"His/her/its head"

(51) Okùba ò

money our

"Our money

(52) Okùba wa

money their

"Their money"

(53) Okùba mẹn

money your(pl)

"Your(pl) money"

From the examples in (45-53), we can identify the forms of the possessive pronouns in Arigidi. The forms are shown in table 4 below:

\begin{tabular}{ll} 
first person singular possessive pronoun & rọn \\
second person singular possessive pronoun & rin \\
third person singular possessive pronoun & $\grave{v} \dot{v}$ \\
first person plural possessive pronoun & $\grave{o}$ \\
second person plural possessive pronoun & $w a$ \\
third person plural possessive pronoun & $m e ̣ n$ \\
\multicolumn{2}{c}{ Table 4. Forms of the Possessive Pronouns in Arigidi }
\end{tabular}

Possessive pronouns in Arigidi can be classified as short pronouns because they do not possess any attributes of the long (emphatic) pronouns. Also, the third person singular possessive pronoun in Arigidi has no definite form. In examples (45-48) where the third person singular possessive 
pronoun occurs, it was observed that the last vowel of the noun (i.e. the possessor) is always reduplicated with a low ['] and high ['] tone respectively to indicate possession or ownership. It is the reduplicated vowel that functions as the 3 SG possessive pronoun in Arigidi.

\section{Conclusion}

This study presented a functional analysis of pronouns in Arigidi with focus on their forms and functions. It was revealed that just like Standard Yorùbá, Arigidi attests three types of pronouns; short pronouns, long (emphatic) pronouns and possessive pronouns. Findings revealed that the forms attested as the short subject pronouns were derived from their underlying forms through some phono-syntactic processes. It was also discovered that $a$ the first element in the position of the $3 \mathrm{SG}$ subject pronoun in certain constructions in Arigidi is not a pronoun but a preverbal element similar to the Yorùbá HTS which marks tense and aspect (Awóbùlúyì 1992, Oshodi 2011b, 2013). Furthermore, the 3SG short object pronoun in Arigidi has no definite form and it is always covert. The same thing goes for the 3SG possessive (genitival) pronoun which also has no definite form. It usually reduplicates the last vowel of the noun (i.e. possessor) which precedes it to express possession or ownership. Pronouns in Arigidi were also discovered to perform similar functions like those in Standard Yorùbá and act more like nouns in their relationship with other lexical items in sentences. These findings further confirm the strong linguistic affinity between Arigidi and Standard Yorùbá. Finally, it was revealed that the lexical items tagged pronouns in Arigidi perform more functions beyond the main function assigned to them in traditional grammar unlike what happens in European languages like English and French. This further confirms that language specific rules are needed to affirm the functional role of lexical items based on their relationship with other lexical items in individual language.

\section{References}

Adéșọlá, O. 2004. Coda deletion in the Yorùbá phonology. In A. Akínbíyi, \& O. Adéșọlá (Eds.). Proceedings of the 4th World Congress of African Linguistics. Cologne: Ruediger Koeppt Ventag.

Adéșọlá, O. 2005. Pronouns and operators-A bar dependencies and relations in Yorùbá. Unpublished Ph.D. Dissertation. New Jersey: Rutgers, the State University of New Jersey.

Awóbùlúyì, O. 1978. Essentials of Yorùbá grammar. Ibadan: Oxford University Press.

Awóbùlúyì, O. 1992. Aspects of contemporary standard Yorùbá in dialectological perspectives:

In Akínwùnmí Ìshọ̀lá (ed.), New Findings in Yorùbá Studies. J. F. Ọúnjọ memorial lectures organizing committee.

Awóbùlúyì, O. 2008. Ẹkộ İṣẹ̀dá-Ọ̀ọ̣ Yorùbá. Àkúrẹe: Montem Paerbacks.

Bámgbóṣe, A. 1967. A short Yoruba grammar. Ibadan: Heinemann Educational Book (Nigeria) LTD.

Bámgbóṣé, A. 1990. Fonọ́lọjì àti gírámà Yorùbá. Ìbàdàn. University Press PLC.

Bennet, P., \& Sterk, J. P. 1977. South Central Niger-Congo: A reclassification. Studies in African Linguistics, 8: 241-273.

Capo, H. B. C. 1989. "Defoid” in Niger-Congo languages. Bendor Samuel (ed.) University Press of America.

Dinneen, F. 1967. An introduction to general linguistics. Holt, Rinehart and Winston, The University of Michigan 
Greenberg, J. 1963. The languages of Africa. The Hague I.J.L.A.L. Publications 25 of the Indiana University Research Centre in Anthropology, Folklore Linguistics Bloomington. Indiana University Press.

Fádọọ̀, J. O. 2014. Akokoid comparative wordlist. Journal of Advances in Linguistics, Vol 3, No. 1, 156-169.

Hoffman, C. 1974. Nigerian languages by language families. Mimeograph. Ibadan.

Lorena, T. 2012. Ethnologue: Languages of the world, SIL International. Retrieved on September 28, 2011, from the Website temoa: Open Educational Resources (OER) Portal at http://www.temoa.info/node/24358

Manfredi, V. 1987. Antilogophoricity as domain extension in İgbò and Yorùbá. Niger-Congo Syntax and Semantics, 1, 97-117.

Ohiri-Anichie, C. 2006. The place of Akokoid in Benue-Congo. In O. M. Ndimele, C. I. Ikekeonwu, and B. M. Mba (eds.). Language and Economic Reforms in Nigeria PortHarcourt: $M$ and J. Grand. Orbit Communications Ltd and Emai Press.

Oshodi, B. 2011a. A reference grammar of Arigidi. Montem Paperbacks. Akure, Nigeria.

Oshodi, B. 2011b. The HTS (high tone syllable) in Arigidi: An introduction. Nordic Journal of African Studies University of Helsinki. 20(4), 263-275.

Oshodi, B. 2013. Is ó HTS (high tone syllable) a pronoun or a preverbal element in Yorùbá? Further evidence from Ò̀ọ̀ Dialect. Ruwaza Africa: A Journal of Contemporary Research in Humanities \& Social Science, Egerton University, Kenya. Vol. 2. No 1, 212-223.

Oshodi, B. 2016a. The epenthetic vowel and negation in Arigidi and Òwọ̀: Another evidence of Arigidi-Yorùbá affinity. Studies in Linguistics, Kangwon National University, Republic of Korea, 40, 423-450.

Pronoun. 2003. In Merriam-Webster's dictionary (11th ed.). Springfield, MA: Merriam-Webster Sells, P. 1987. Aspects of logophoricity. Linguistic Inquiry, 18, 445-481.

Yusuf, O. 1995. Yorùbá àkọtun: Ní ilànà ònídàrọ. İjẹbú-òde: Șhebíotimọ Publications. 